\title{
TERRACE TYPES AND VEGETATION DYNAMICS ON MACQUARIE ISLAND
}

\author{
by P.M. Selkirk, D.A. Adamson and R.D. Seppelt
}

(with two text-figures and three plates)

SELKIRK,P.M., ADAMSON, D.A. \& SEPPELT, R.D., 1988 (viii): Terrace types and vegetation dynamics on Macquarie Island. Pap. Proc. R. Soc. Tasm., 122(1): 59 64, 3 pl. Papers presented at the Macquarie Island Symposium, Hobart, May 1987. https://doi.org/10.26749/rstpp.122.1.59

ISSN 0080 4703. School of Biological Sciences, Macquarie University, New South Wales, Australia 2109; and Antarctic Division, Channel Highway, Kingston, Tasmania, Australia 7150.

Feld mark vegetation occurs extensively on the plateau of Macquarie Island above about $200 \mathrm{~m}$. Alternating stripes of vegetation and gravel are frequently associated with terraced terrain. Detailed study of 38 terraced sites with non-windward aspects shows vegetation terrace interaction to be active under present climatic conditions. Wind, moisture, hillslope, slope stability and vegetation all affect terrace form.

Key Words: feldmark vegetation, terrace formation, vegetation dynamics, Macquarie Island.

\section{INTRODUCTION}

Macquarie Island is a small subantarctic island in the Southern Ocean, southeast of Tasmania, in the path of strong west to northwesterly winds. Feldmark (or fellfield or fjaeldmark) vegetation occurs extensively on the island plateau above about $200 \mathrm{~m}$ altitude. Amongst the 63 plant species recorded in the feldmark, bryophytes and the cushion-forming vascular plant, Azorella selago, are dominant. Vegetation cover is extremely variable. Large expanses of gravelcovered ground are common (Selkirk \& Seppelt 1984).

Vegetation disposition ranges from regularly alternating stripes of vegetation and gravel to irregular vegetation patches amongst gravel. Regular striping may be associated with "steps and stairs" terrain. "Leeward terraces" on east-facing slopes, on which vegetation forms risers and gravel forms treads of the stairs, have been described by Taylor (1955). "Wind ward terraces" on west-facing slopes are less regular, with gravel risers and vegetation treads. Taylor interpreted both terrace types as responses by vegetation to the present prevailing strong westerly winds. Löffler el al. (1983) and Löffler (1983) regarded windward terraces as wind formed, but leeward terraces as relict solifluction landforms developed during a former, more severe climate. They described terraces on slopes with neither windward nor leeward aspects as intermediate in form.

Ashton \& Gill (1965) described in detail the structure of terraces on windward slopes on North
Mountain and the involvement of wind in their formation, maintenance and gradual upslope progression.

This paper concentrates on terraces on hills with other than windward aspects, following observation of a wide variety of terrace forms and dimensions; wind, moisture, hillslope, slope stability and vegetation all affect terrace form. Studies were also made of dynamic features of terraces which imply that they are not merely inherited landforms from a glacial period, but that development, stabilisation and destruction are all contemporary processes. Although terrace initiation is difficult to observe, it is believed that this could develop on unterraced hillslopes in the present environment, as, for example, following landslip.

\section{CLIMATIC FACTORS AND FROST SORTING}

Although climatic records for Macquarie Island indicate that average daily minimum, mean and maximum temperatures are all above $0^{\circ} \mathrm{C}, 51$ days per year, on average, have air temperatures below zero, and 99 days per year have surface ground temperatures below zero (Löffler 1983). Ground temperatures at depths greater than $100 \mathrm{~mm}$ approximate air temperatures, so soil frost formation is restricted to the surface $100 \mathrm{~mm}$ or so (Löffler el al. 1983).

As meteorological data on the island are recorded at $6 \mathrm{~m}$ a.s.l., and temperatures are approximately $1^{\circ} \mathrm{C}$ lower for each $100 \mathrm{~m}$ increase 
in altitude, occurrence of ground frost at plateau sites is likely to be significantly more frequent. Löffler (1983) estimated there would be approximately 170 days with frost at $200 \mathrm{~m}$ a.s.1. Precipitation averages about $900 \mathrm{~mm}$ per annum at the isthmus weatherstation, and $42 \%$ more than this at the northern end of the plateau (Mallis, this volume) so moisture for needle ice formation on the plateau is abundant.

On bare ground on the plateau, stone sorting resulting from frost action is frequently seen. Löffler et al. (1983) described small stone polygons on level ground, and stone stripes on ground sloping at between $2^{\circ}$ and $20^{\circ}$. We have also observed frost-mediated general downslope movement of gravel, sorted so that larger stones are towards the edges and front of active chutes.

\section{VEGETATION AND TERRACE OBSERVATIONS}

Vegetation disposition in feldmark is clearly associated with hillslope, varying with increasing steepness.

\section{No Slope}

On more or less level ground, vegetation may consist of irregularly placed moss polsters and Azorella cushions (e.g. Boot Hill) or elongated stripes of moss, aligned at an angle of about $20^{\circ}$ to the north of prevailing wind direction (e.g. on Windy Ridge: an unofficial name for a ridge $1 \mathrm{~km}$ southeast of Mt Fletcher). In some areas with slopes of less than $2^{\circ}$ these moss stripes may be arranged in bands of alternating vegetation and bare gravel, associated with very slight terracing of the ground (e.g. Windy Ridge) (plate 1). This type of vegetation stripe has not previously been described from Macquarie Island.

\section{Gentle Slopes}

On gently sloping ground (about $0-15^{\circ}$ ) hillsides are markedly terraced approximately along the contours, with vegetated terrace risers and gravel-covered terrace treads (e.g. at Ratsak Junction: an unofficial name for the track junction on the southeast flank of Mt Martin) (plate 2 and fig. 1A). Treads may slope slightly $\left(1-2^{\circ}\right)$ either outwards or inwards, and usually slope slightly $\left(0-5^{\circ}\right)$ along their length (fig. 2). These are the leeward terraces of Taylor (1955), Loffler et al. (1983) and Löffler (1983).

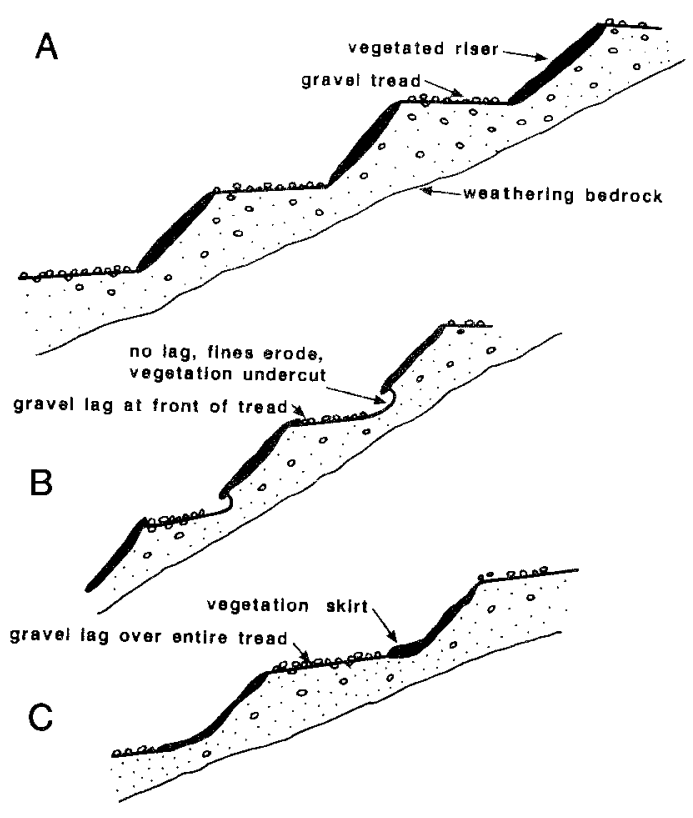

FIG. I - Notional sections through terraces approximately along contours. (A) Risers are vegetated, treads have gravel lag. (B) Vegetation on risers c'an be undercut at base when fines are eroded from a surface lacking gravel lag. (C) Vegetation extending as a "skirt" from the riser above can help stabilise the back of a tread.

Terrace vegetation dynamics yield several minor variations in the details of plant and gravel boundaries.

At the back of a tread, near the base of the vegetation of the riser above, stirring by needle ice action, followed by water washing down the riser, can gradually erode fine material away (fig. 1B) Over time, this will steepen the angle of the riser, and, as vegetation slowly grows into gravel at the front of the tread above, the riser will move upslope. The hill remains terraced but individual terraces are not fixed in their form or positions on the slope. In other cases, the back of the tread may be well stabilised by vegetation extending onto the tread from the riser above, as described below (fig. 1C).

Vegetation on the risers is predominantly Azorella, with Agrostis magellanica, Festuca contracta, Acaena minor, Ranunculus biternatus and a variety of bryophytes and lichens. Rhacomitrium crispulum and Ditrichum strictum sometimes form a "skirt" along the base of the riser 


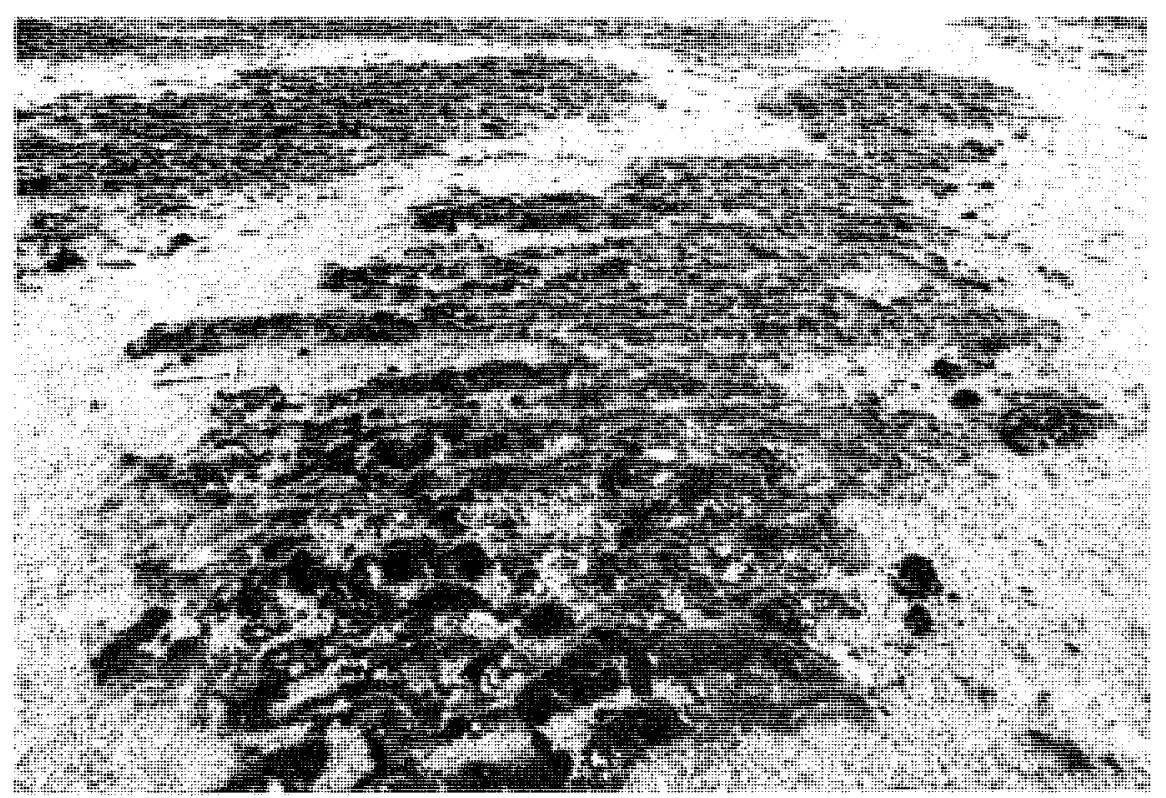

PLATE I

Bands of moss stripes alternate with bare gravel on very slightly terraced ground on Windy Ridge, approximately I km southeast of Mt Fletcher. Geology hammer gives scale.

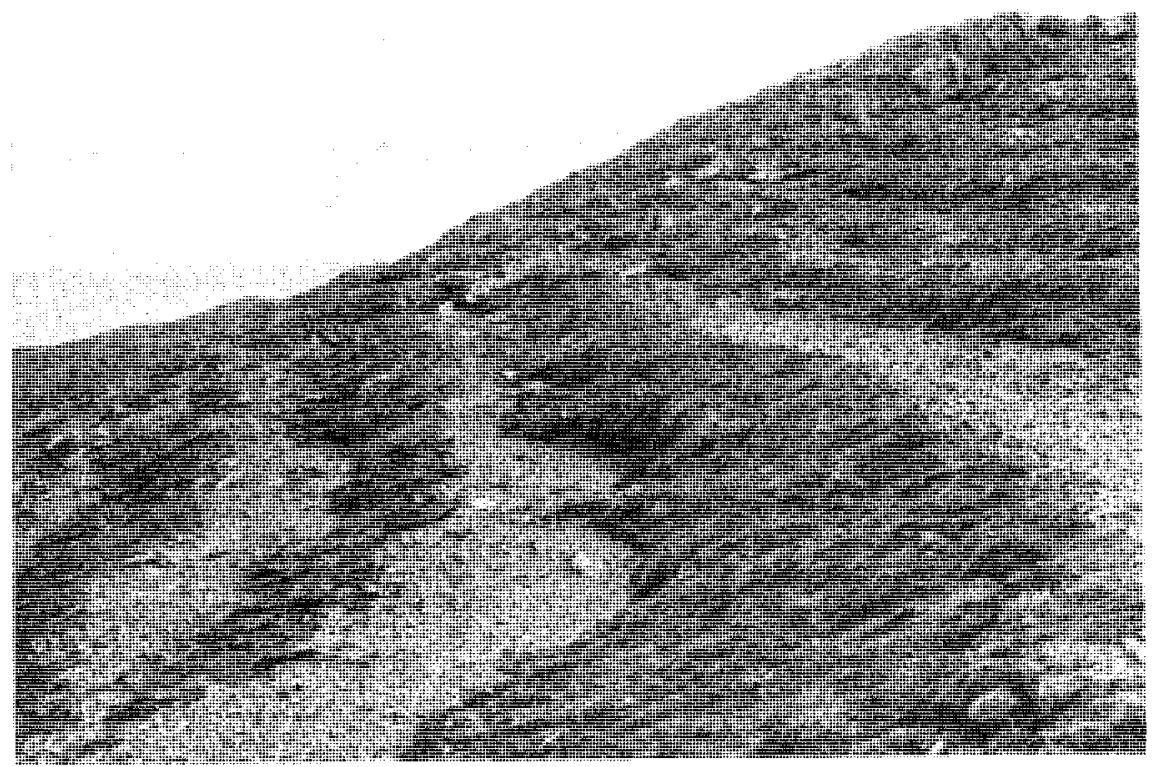

PLATE 2

Hillslope terraced approximately along contours with vegetated risers and gravel covered treads, southeast flank of Mt Martin. 


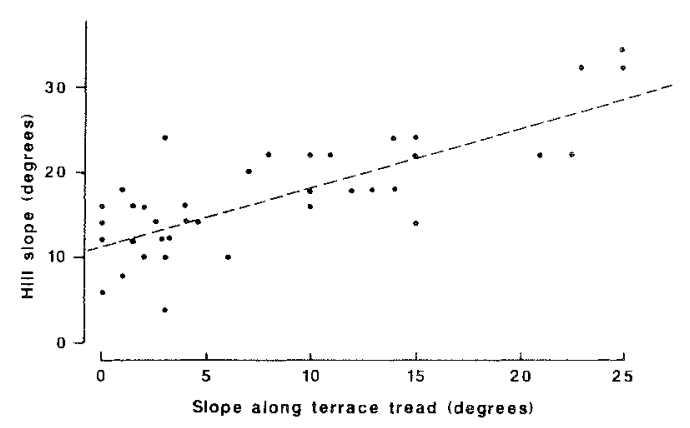

FIG. 2 - Plot of slope along terrace tread against general hillslope for 38 sites. The change from subhorizontal terrace treads to sloping treads occurs at hillslopes of approximately $I^{\circ}$. Regressionequation: hillslope $=10.9+0.71$ treadslope.

extending a variable distance onto the back (or inner edge) of the gravel tread. This "skirt" helps stabilise the terraces and minimise their upslope migration by protecting the back of the tread and foot of the riser from erosion.

Frost sorting of surface gravel on treads is common, with larger stones sorting to the front, or outer edge of the tread. Similar sorting occurs on the chutes which lead from one tread to the tread below. Only a few scattered polsters of Ditrichum strictum, Andreaea spp. and Rhacomitrium crispulum occur on treads on which frost sorting appears active. On such treads, a high proportion of fines is visible at the surface amongst the gravel. Oin treads where only a very small proportion of fines is visible, frost sorting of gravel appears less active, and more moss polsters, small areas of Rhacomitrium crispulum turf, small Azorella selago clumps and runners of Ranunculus biternatus and Acaena minor occur.

In a few places, completely vegetated terraces occur (e.g. southwest of Mt Martin; west of the largest of the three lakes south of Mt Blair). These complctely vegetated terraces do not appear to have been described previously on Macquarie Island. The terrace tread surface becomes completely vegetated, presumably having stabilised after fines have been washed out, frost heaving has decreased, and additional supply of debris from above has been exhausted.

Measured across their surfaces at right angles to contours, treads and risers are wider on gently sloping hillsides than on slightly steeper slopes.
This is often visible on a single hillside, terraced approximately parallel to its contours, where wide terraces occur low on the hill and narrower terraces higher up.

Where terrace treads are not quite parallel to contours but slope slightly along their length, the tread may itself be terraced with alternating vegetation and gravel stripes. This gives the appearance of intersecting terraces (e.g. approximately $1 \mathrm{~km}$ south of Mt Martin). Rarely, on much steeper slopes, completely unvegetated transverse terracing of gravel treads was observed (e.g. on the southeast flank of Mt Hamilton).

\section{Moderately Steep Slopes}

On more steeply sloping sites, both terraces and associated vegetation and gravel stripes are oriented at an increasingly steep angle to the contours. Figure 2 shows that this change from subhorizontal or gently sloping terraces occurs at a hillslope of approximately $11^{\circ}$. At a particular site, this threshold seems to be affected by a number of factors, including the size of gravel fragments and proportion of gravel to fines in the tread material, presence of bedrock at or near the surface to which the terrace materials become pinned, available moisture, wind exposure, altitude and hence extent of needle ice formation.

As frost action moves gravel downslope along terrace treads, larger stones are sorted to the outer edges of treads (e.g. southern shoulder of Mt Hamilton) and to the edges of chutes.

It is common to see gravel overriding vegetation at the top of risers (contrary to the observations of Loffler el al. 1983), to see spills of gravel across vegetation onto lower levels (plate 3), and to see chutes of gravel connecting one tread to a lower one (e.g. northeast of Mt Hamilton). Surface water flows downslope from tread to tread along such chutes, washing fine material downwards. The orientation of frost stripes on the treads, where they occur, indicates the direction of gravel movement and erosion in general.

\section{Extremely Steep Slopes}

On slopes on which gravel movement is active, vegetation occurs in patches elongated downslope, alternating with gravel stripes. Terracing is apparent at some such sites (e.g. high on the south face of Mt Hamilton). 


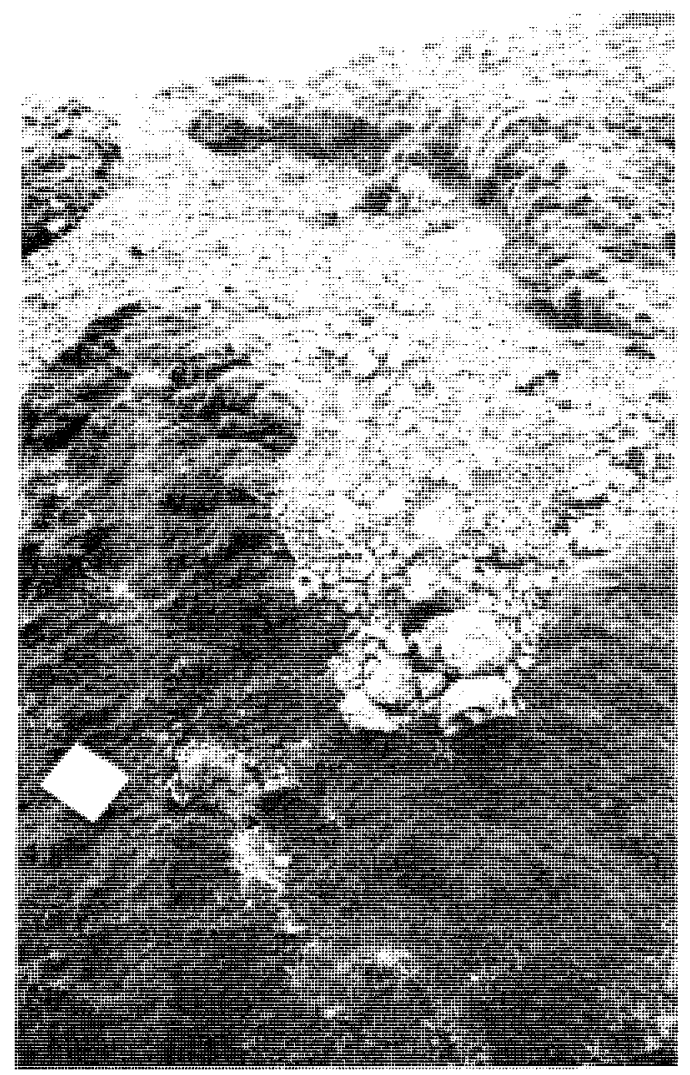

\section{PLATE 3}

Gravel commonly overrides vegetation at top of risers, spilling across vegetation onto lower levels. Notebook $(150 \times 90 \mathrm{~mm})$ gives scale.

\section{Other Sites}

Although the terraces so far discussed have vegetated risers, terraces are not necessarily dependent on vegetation banking for either their formation or maintenance. Terracing in completely unvegetated gravel is very occasionally seen (as described at end of "Gentle Slopes" section above). At several sites (e.g. 750 m northeast of Mt Law; at the foot of the southern side of Mt Tulloch) terraces occur in short grassland. Gravel treads are well dotted with Ditrichum strictum polsters; the change of slope from tread to riser occurs in gravel; the upper third of the riser is devoid of vegetation, while the lower two-thirds supports short grassland vegetation (principally Luzula crinita, Agrostis magellanica, Festuca contracta, Acaena minor).
Terrace types and vegetation dyamics

This type of terrace has not previously been described on Macquarie Island.

\section{INTERPRETATION OF TERRACES}

In the Macquarie Island plateau environment there are suitable temperature and moisture conditions for needle ice formation in the $10 \mathrm{p} 100 \mathrm{~mm}$ of soil. When a mixture of fines and gravel is present, frost action causes sorting and, even on gently sloping sites, downslope movement of gravel and removal of fines from the surface leaves a surface lag of gravel. Although strong westerly to northwesterly winds are common on the island, on nonwindward terraced slopes most movement of fines is downslope, washed by water from the almost constant precipitation.

At a few sites unvegetated terraces occur, but more commonly vegetation clothes the risers of terraces, stabilising them. Sorting of stones and downslope movement of gravel occur only on the treads. Gravel particles follow a zigzag path down a terraced slope, via terrace treads and interconnecting gravel chutes. Terracing lengthens the path and reduces the angle of slope down which particles travel during erosion of hillslopes.

Figure 1 and observations of the instability of the surface material imply that the mantle of mineral particles on the hillslopes is mobile and moving downslope, even if the form of the terraces may move upslope. Bedrock surfaces bear no relation to the surface profile: they may be smooth beneath strongly developed terraces. Terracing is a feature of the mobile mantle.

The nearly contour-parallel terraces resemble some forms of unsorted steps described from periglacial environments. Although Washburn (1979) described non-sorted steps as elongated downslope, Embleton \& King (1975) described some forms parallel with slope contours, with vegetated risers and bare treads. Steps merge into stripes running downslope as slope increases. Embleton \& King (1975) also commented that neither steps nor stripes need necessarily be associated with permafrost.

Kirkpatrick (1984) described a change from non-sorted stone steps to non-sorted stone stripes at a general slope angle of approximately $8^{\circ}$ in some alpine areas of Tasmania. There, risers are well vegetated with herbs and shrubs to $0.5 \mathrm{~m}$ tall. Our observations of terraces subparallel to contours on low hillslopes and angled terraces on hillslopes steeper than approximately $11^{\circ}$ seem analagous to Kirkpatrick's. 
Observations show that terrace-vegetation interaction on Macquarie Island is active at present. Although terracing on hillslopes is likely to have been present for a considerable length of time, it is not necessary to postulate that terraces are relict features or that they required a more severe former climate for their formation.

\section{ACKNOWLEDGEMENTS}

Permission from the Macquarie Island Advisory Committee to conduct field work on the island and logistic support from the Australian Antarctic Division are gratefully acknowledged. Financial assistance was provided by the Australian Research Grants Scheme and a Macquarie University Research Grant.

\section{REFERENCES}

ASHTON, D.H. \& GILL, A.M., 1965: Pattern and process in a Macquarie Island feldmark. Proc. R. Soc. Vict., 79: 235-245.

EMBLETON, C. \& KING, C.A.M., 1975: PERIGLACIAL GEOMORPHOLOG Y. John Wiley and Sons, New York.

KIRKPATRICK, J.B., 1984: Tasmanian high mountain vegetation II .... Rocky Hill and Pyramid Mouncain. Pap. Proc. R. Soc. Tasm. 118:5-20.

LOFFLER, E., 1983: Macquarie Island -- eine vom Wind gepragte Naturlandschaft in der SubAntarktis. Polarforschung, 53(1): 5974.

I.OFFLER, E., SULLIVAN, M.E. \& GILLISON, A.N., 1983: Periglacial landforms on Macquarie Island, Subantarctic. Zeirschr. Geomorph. N.F., 27(2): $223-236$

MALLIS, M., 1988: A quantitative investigation into scavenging of airborne sea salt over Macquarie Island. Pap. Proc. R. Soc. Tasm., 122(1): $121-128$

SELKIRK, P.M. \& SEPPELT, R.D., 1984: Fellfield on Macquarie Island. Tasm. Nat., 78: 24-26.

TAYLOR, B.W., 1955; The flora, vegetation and soils of Macquarie Island. ANARE Rep., Ser. B(11), Botany.

WASHBURN, A.L., 1979: GEOCRYOLOGY. Edward Arnold, London.

(accepled 2 October 1987) 